\title{
Grazing Intensity and Spatial Heterogeneity in Bare Soil in a Grazing-Resistant Grassland
}

\author{
David J. Augustine, ${ }^{1}$ D. Terrance Booth, ${ }^{2}$ Samuel E. Cox, ${ }^{3}$ and Justin D. Derner ${ }^{4}$
}

\author{
Authors are ${ }^{1}$ Research Ecologist, USDA-ARS, Rangeland Resources Research Unit, Fort Collins, CO 80526, USA; ${ }^{2}$ Rangeland Scientist, Rangeland \\ Resources Research Unit, Cheyenne, WY 82009, USA; ${ }^{3}$ Natural Resource Specialist, USDI-BLM, Cheyenne, WY 82009, USA; and ${ }^{4}$ Rangeland Scientist \\ and Research Leader, USDA-ARS, Rangeland Resources Research Unit, Cheyenne, WY 82009, USA.
}

\begin{abstract}
We used very large scale aerial (VLSA) photography to quantify spatial patterns in bare soil in the northeastern Colorado shortgrass steppe. Using three pairs of pastures stocked at moderate $\left(0.6\right.$ animal unit months [AUM] $\cdot$ ha $\left.^{-1}\right)$ versus very heavy $\left(1.2 \mathrm{AUM} \cdot \mathrm{ha}^{-1}\right)$ rates, we detected greater bare soil under very heavy $($ mean $=22.5 \%)$ versus moderate stocking $($ mean $=13.5 \% ; P=0.053)$ and a lower coefficient of variation across pastures under very heavy $(0.48)$ versus moderate stocking $(0.75 ; P=0.032)$. Bare soil exhibited significant positive spatial autocorrelation across distances of $60-120 \mathrm{~m}$ under moderate stocking (Moran's $I=0.14)$, while patchiness at this scale was eliminated under very heavy grazing $(I=-0.05)$. Across distances of 120-480 m, we observed no spatial autocorrelation with either stocking rate. Spatial autocorrelation was greatest at a separation distance of $2 \mathrm{~m}(I=0.48-0.58)$ but was unaffected by stocking rate at this scale. Thus, very heavy grazing did not increase spatial autocorrelation in bare soil across scales of $2-480 \mathrm{~m}$. Means and variability in the distribution of bare soil were not influenced by ecological site. Bare soil increased primarily at the scale of individual plant clusters through both increases in the density of small $(2-20 \mathrm{~cm})$ bare patch intercepts and increases in the frequency of bare patch intercepts of 20-60 cm (rather than $<20 \mathrm{~cm}$ ). Our approach demonstrates the utility of VLSA for analyzing interactions between grazing and other landscape features and highlights the importance of spatially explicit sampling across broad scales (pastures) while testing for potential shifts in patchiness of bare soil at the scale of plant interspaces.
\end{abstract}

\section{Resumen}

Utilizamos fotografía de escalas aéreas muy altas (VLSA) para cuantificar patrones espaciales en suelo desnudo en un pastizal de pastos cortos del noreste de Colorado. Usando tres pares de pastizales con carga animal moderada (0.6 unidades animal por mes $\left.[\mathrm{AUM}] \cdot \mathrm{ha}^{-1}\right)$ comparándolos contra pastizales con cargas animales altas $\left(1.2 \mathrm{AUM} \cdot \mathrm{ha}^{-1}\right)$, detectamos una mayor cantidad de suelo desnudo en lugares con cargas animales altas (media $=22.5 \%$ ) en comparación con las cargas animales moderadas $($ mean $=13.5 \% ; P=0.053)$, y un bajo coeficiente de variación a través de pastizales con cargas animales muy altas $(0.48)$ en comparación con cargas animales moderadas $(0.75 ; P=0.032)$. El suelo desnudo presentó auto-correlaciones significativas y positivas espaciales en las distancia de 60 a $120 \mathrm{~m}$ bajo una carga animal moderada (Moran's $I=0.14$ ), mientras, la agregación a esta escala se eliminó dentro de áreas de carga animal alta $(I=-0.05)$. A la escala de 120-480 m, no observamos correlación alguna con ninguna carga animal. La auto correlación espacial fue la mayor en la separación de $2 \mathrm{~m}(I=0.48-0.58)$ pero no fue afectada por ningún nivel de carga animal en esta escala. De esta manera los lugares pastoreados fuertemente no incrementaron la auto correlación espacial en suelo desnudo en la escala de 2-480 m. Las medias y la variabilidad en la distribución de suelo desnudo no fueron influenciadas por los sitios ecológicos. El suelo desnudo se incrementó principalmente en las escalas de plantas individuales y agregados, ambas mediante el incremento en la densidad de pequeñas intercepciones de suelo desnudo (2$20 \mathrm{~cm}$ ), e incrementos en la frecuencia de intercepciones de suelo desnudo de 20 a $60 \mathrm{~m}$ (en lugar de $<20 \mathrm{~cm}$ ). Nuestro enfoque demuestra la utilidad de VLSA para analizar interacciones entre el pastoreo y otras características del paisaje, y recalca la importancia del muestreo espacialmente explicito a través de amplias escalas (pastizales) mientras se evalúa el potencial de cambio de áreas a suelo desnudo a la escala de espacios entre plantas.

Key Words: ecological sites, piosphere, shortgrass steppe, spatial autocorrelation, state and transition models, topographic wetness index

\section{INTRODUCTION}

Presented at the symposium "Very-High Resolution Imaging for Resources Monitoring," 9-10 February 2011, Billings, MT, USA.

The USDA-ARS, Northern Plains Area, is an equal opportunity provider and employer. Mention of trade names in this publication is solely for the purpose of providing specific information and does not imply recommendation or endorsement by USDA.

Correspondence: David J. Augustine, USDA-Agricultural Research Service, 1701 Centre Ave, Fort Collins, C0 80526, USA. Email: David.Augustine@ars.usda.gov

Manuscript received 3 January 2011; manuscript accepted 22 September 2011.
Spatial patterns in the distribution of vegetation cover have been proposed as indicators of rangeland condition because loss of vegetation cover can initially occur in particular landscape positions and then spread laterally (Bestelmeyer et al. 2006; Kefi et al. 2007; Stokes et al. 2009). However, the ways that grazers influence spatial heterogeneity in vegetation cover are complex and difficult to predict, as it often reflects an 
interaction between factors influencing animal foraging behavior and the inherent vegetation patterns that would occur in the absence of herbivory (reviewed by Adler et al. 2001). Studies of grazing and vegetation heterogeneity have traditionally been based either on measurements conducted at limited spatial extents (Bakker et al. 1983; Adler and Lauenroth 2000; Augustine and Frank 2001) or on simulation modeling (Weber et al. 1998; Klausmeier 1999; Adler and Hall 2005). Rangeland monitoring has included extensive use of "representative areas," which may not be able to detect the development of bare soil patches until they have become widespread within an area (Interagency Technical Team 1996; Herrick et al. 2005; Watson et al. 2007). Traditionally, remote sensing of rangeland vegetation at broad spatial extents has not provided sufficient resolution at the scale of individual herbaceous plants and their interspaces to assess spatial patterns in herbaceous vegetation cover (Ludwig et al. 2007b). Ground-based sampling can be used to quantify spatial heterogeneity in rangeland vegetation (e.g., Fuhlendorf and Smeins 1999; Rietkerk et al. 2000; Augustine 2003) but often involves substantial labor and travel costs.

More recently, very large scale aerial (VLSA) photography has enabled sampling rangelands at both high resolution (individual plants and interspaces) and broad spatial extents (e.g., pastures, watersheds, or landscapes; Booth and Cox 2008). VLSA photography can quantify bare soil at scales of $1-10 \mathrm{~m}^{2}$, where we may expect aggregration of plant interspaces into larger bare patches to initially occur. The method also allows for assessment of aggregation in bare soil distribution at larger spatial scales (across distances $\geq 100 \mathrm{~m}$, up to pastures, watersheds, or landscapes). Measurements from VLSA photographs can be analyzed in relation to factors such as topography, soils, ecological sites, and grazing management practices. Erosion in rangelands can depend on both the extent and the spatial configuration of bare soil, with high rates occurring where bare patches of several square meters or larger are aggregated or connected in lower hillslope positions (e.g., Ludwig et al. 2005, 2007a; Bartley et al. 2006; Urgeghe et al. 2010). In contrast, where bare patches are small $\left(<2 \mathrm{~m}^{2}\right)$ and interspersed with vegetated areas, erosional losses may be minimal (Blackburn and Pierson 1994; Ludwig et al. 2007a; Bartley et al. 2010). Thus, key issues in rangeland monitoring and management are 1) detecting the initial development of bare patches at scales important to the site, 2) assessing whether they are aggregated at larger scales, and 3) linking bare patch size and location to grazing management practices, topography, and soils.

Topography and water sources can strongly influence cattle grazing patterns and hence potentially influence patterns of vegetation cover. Plant production is often suppressed in the immediate vicinity (e.g., within $100 \mathrm{~m}$ ) of water sources, but spatial patterns at larger distances from water can vary considerably among rangeland ecosystems and stocking rates (Fuhlendorf and Smeins 1999; Adler and Hall 2005; Sasaki et al. 2008). Thus, water locations should be considered as a covariate in assessments of bare soil patterns in rangelands (Pringle and Landsberg 2004). Topography also influences vegetation through its direct influence on moisture availability and indirectly through cattle grazing. The degree to which increased moisture availability and plant production in lowlands may be offset by preferential cattle grazing in these locations can depend on site-specific aspects of both the plant community and grazing management. Topography is thus an important factor to consider in assessments of bare soil distribution.

The shortgrass steppe in the southwestern portion of North America's Great Plains (Lauenroth et al. 1999) has a long history of research evaluating stocking rate effects on soils, plants, and fauna (Lauenroth and Burke 2008). The shortgrass steppe is more resistant to grazing in terms of plant productivity, plant species composition, and sustained livestock production than most other rangelands worldwide (Bement 1969; Milchunas and Lauenroth 1993; Milchunas et al. 2008). Past studies have contrasted the recommended "moderate" stocking rate for this region (0.6 animal unit months $\left.[\mathrm{AUM}] \cdot \mathrm{ha}^{-1}\right)$, which removes $\sim 40 \%$ of the average annual aboveground net primary production (ANPP), with "heavy" stocking (0.9 AUM $\cdot \mathrm{ha}^{-1}$ ), which removes $\sim 60 \%$ of ANPP (reviewed by Milchunas et al. 2008). Although heavy stocking reduces ANPP (Milchunas et al. 1994) and weight gains of individual cattle (Bement 1969; Hart and Ashby 1998), heavy stocking may not lead to long-term loss of vegetation cover or increased bare soil exposure (Milchunas et al. 1989). Rather, the dominant warm-season grasses, blue grama (Bouteloua gracilis [Willd. ex Kunth] Lag. ex Griffiths) and buffalograss (Buchloe dactyloides [Nutt.] Engelm.), are largely resistant to the level of defoliation imposed by heavy stocking rates, resulting in the development of a homogeneous, short-statured, prostrate vegetative growth form often referred to as "grazing lawns" (Milchunas and Lauenroth 1989; Milchunas et al. 1989).

Little is known about how higher stocking rates may influence spatial patterns of vegetation cover and bare soil exposure. As grazing intensity increases, bare soil could increase through 1) increased density of small bare patches in plant interspaces and 2) increased size of bare patches as they expand and coalesce. Of particular interest for rangeland management and monitoring is identifying the conditions under which this latter process occurs and the spatial scale of bare patch formation. Our first objective was to determine whether intense grazing can significantly suppress vegetation cover in this grazing-resistant grassland. We conducted three trials comparing very heavy stocking rates $(1.2$ AUM $\cdot \mathrm{ha}^{-1}$, two times the recommended moderate stocking rate) to paired, moderately stocked pastures $\left(0.6 \mathrm{AUM} \cdot \mathrm{ha}^{-1}\right)$ and used VLSA photography to measure the distribution of bare soil in each pair of pastures (Booth and Cox 2008). We predicted that under very heavy grazing, bare soil patch size would increase to a greater degree 1) in the vicinity of water sources and 2) at upper topographic positions that do not receive water inputs from run-on or subsurface water movement. Based on the idea that formation of bare soil patches larger than a square meter may be an important indicator of shifts in vegetation condition, we tested for spatial autocorrelation in bare soil across distances of 2-480 m and evaluated the degree to which soils, topography, and distance to water contribute to patterns in the distribution of bare soil under very heavy versus moderate stocking rates.

\section{METHODS}

\section{Study Area}

The Central Plains Experimental Range is located $40 \mathrm{~km}$ northeast of Fort Collins, Colorado (lat $40^{\circ} 49^{\prime} \mathrm{N}$, long $107^{\circ} 47^{\prime} \mathrm{W}$ ), in the northern portion of the shortgrass steppe (Lauenroth and Burke 
2008). Long-term mean annual precipitation (1939-2009) is $342 \mathrm{~mm}$, of which approximately 70\% occurs between April and August. Topography is flat to gently rolling. Vegetation is dominated by the warm-season perennial shortgrasses blue grama and buffalograss, which typically make up $>80 \%$ of basal vegetation cover in both uplands and lowlands; other plants include prickly pear cactus (Opuntia polyacantha) and cool-season gramminoids (Carex eleocharis, Pascopyrum smithii, and Hesperostipa comata; Milchunas et al. 1989; Varnamkhasti et al. 1995; Lauenroth and Burke 2008). The Loamy Plains ecological site comprises the majority of the study area (US Department of Agriculture, Natural Resources Conservation Service [USDA, NRCS] 2007).

\section{Experimental Design and Vegetation Measurements}

In 2001, we selected two pastures grazed for the 14 preceding years at a moderate stocking rate $\left(0.6 \mathrm{AUM} \cdot \mathrm{ha}^{-1}\right)$. Each summer during 2001-2003, the northern square-shaped 65-ha pasture was grazed at the same moderate stocking rate, while the southern square-shaped pasture was split diagonally, with half (32.5 ha) of the pasture grazed at a very heavy stocking rate $\left(1.2 \mathrm{AUM} \cdot \mathrm{ha}^{-1}\right)$ and the other half ungrazed. Grazing began in mid-May each summer and continued through midOctober. The grazing treatments encompassed a near-average precipitation year in 2001 (356 $\mathrm{mm})$, a drought in 2002 (243 mm), and a near-average year in 2003 (322 mm). Cattle were removed from pastures in mid-August 2002, resulting in only a 3-mo grazing season. Actual stocking rate achieved in the very heavy treatment over the three grazing seasons was 1.0 AUM $\cdot \mathrm{ha}^{-1}$. The range in elevation and slope was $20 \mathrm{~m}$ and 0 $7^{\circ}$ for the very heavily grazed pasture, and $26 \mathrm{~m}$ and $0-9^{\circ}$ for the moderately grazed pasture. Vegetation cover was measured in both pastures in May 2004 (early in the growing season as vegetation growth was just beginning) using an aerial sampling method that acquired 1-mm ground sample distance (GSD) resolution, color (red, green, blue), digital images taken at approximately $100 \mathrm{~m}$ above ground level (AGL; for detailed description of the sampling method, see Booth and Cox 2008). The aerial sampling method was tested against ground sampling using color digital images taken at 2-m AGL and verified to produce comparable results (Booth and Cox 2008).

In 2004, we selected two additional pairs of square, 65-ha pastures with a 20-yr history of moderate stocking. One pasture in each pair was stocked at the very heavy level (1.11.2 AUM $\left.\cdot \mathrm{ha}^{-1}\right)$, while the other pasture in each pair remained at the moderate stocking level $\left(0.6 \mathrm{AUM} \cdot \mathrm{ha}^{-1}\right)$. Treatments were applied for four grazing seasons (2004-2007). The previously described aerial photographic method was used to obtain 1-mm GSD resolution color digital images from these pastures in early May 2008 (early in the growing season as vegetation growth was just beginning), with approximately 100-m intervals between photographs in both north-south and east-west directions. The grazing treatments encompassed a drought in 2004 (293 mm), a wet year in 2005 (370 mm), a drought in 2006 (300 mm), and a near-average year in 2007 (350 $\mathrm{mm})$. Thus, all the grazing trials experienced a drought 2 yr prior to the VLSA sampling and near-average precipitation $1 \mathrm{yr}$ prior to VLSA sampling. The range in elevation and slope within pastures was $26 \mathrm{~m}$ and $0-9^{\circ}$.
The aerial surveys used an aircraft equipped with a navigation system based on a global positioning system (GPS) enabled with the Wide Area Augmentation System to improve the accuracy of the GPS en route, a camera triggering system, and a laser range finder for measurement of altitude. Raw images with a $3 \times 4 \mathrm{~m}$ field of view were systematically acquired using planned GPS coordinates in a sampling grid that covered the target pastures. Images were converted to TIF format and analyzed manually using SamplePoint software (Booth et al. 2006a) based on a 100-point systematic grid of pixels within each photograph. The software facilitates point sampling of digital images. Because the sample point is always a single pixel and image GSD is $<1 \mathrm{~mm}$, the analysis has a potential accuracy of $92 \%$, including errors due to pixel mixing, which are inherent in image analysis methods (Booth et al. 2006a). Sample points were classified as green grass, green forbs, green subshrubs, standing dead vegetation, litter, cactus, dung, or bare soil.

We measured bare soil exposure as the percent of an image not covered by any type of aboveground plant mass (standing plant mass, portions of plant crowns that are aboveground, and plant litter) when viewed vertically from above the plant canopy. In shortgrass steppe, bare patches occur primarily within a background matrix of vegetation cover. We report all findings in terms of bare soil but note that vegetation cover is simply $100 \%$ minus bare soil. Our method has been validated in multiple rangeland types against a variety of ground-based methods that similarly measure the area not covered by plant mass when viewed vertically from above the canopy (Seefeldt and Booth 2006; Booth and Cox 2008). However, we note that this method is not directly comparable to measurements of bare soil at the ground surface (i.e., beneath the plant canopy), which have been reported in some studies of the shortgrass steppe (e.g., Milchunas et al. 1989; Coffin et al. 1996).

To further evaluate the distribution of bare soil within the plots, we used a software program (ImageMeasurement ver. 2.04; Booth et al. 2006b) to overlay each photograph with three 3-m transects running parallel to the 3-m edge and spaced systematically across the 4-m edge. Following line-transect methods described by Herrick et al. (2005), we measured the length of each bare soil patch (i.e., contiguous area with no plant or litter cover) that intersected $>2 \mathrm{~cm}$ of each transect.

\section{Covariates of Bare Soil}

We quantified topographic variability using a topographic wetness index (TWI) derived from a $10-\mathrm{m}$ resolution digital elevation model for the study area. For a given pixel at location $i$, TWI was calculated following Beven and Kirkby (1979) as $\mathrm{TWI}_{i}=\ln (a / \tan \beta)$, where $a$ is the contributing upslope area (CA) and $\beta$ is the local slope at pixel $i$. TWI calculations were implemented in ArcGIS (ver. 9.3; ESRI, Redlands, CA) using LCaP version 1.0 (Theobald 2007). We used the TWI calculation option that incorporated differences between north- and south-facing aspects, where the contribution of any given cell to CA was weighted from 0 (xeric) to 1.0 (mesic) based on relative solar insolation (Theobald 2007). Within the study pastures, TWI varied from a minimum of 1.3 in uplands to a maximum of 28.4 in swales. We calculated the average TWI within a $20-\mathrm{m}$ radius of the central coordinate of each aerial photograph. We 
also used ArcGIS to measure the distance from each photograph to the nearest water source within each pasture and to determine the ecological site in which each photograph occurred. In the pastures we studied, $60 \%$ of the photos were in the Loamy Plains ecological site (USDA, NRCS 2007). Additional ecological sites were Shaly Plains, Sandy Plains, and Gravel Breaks.

\section{Statistical Analyses}

To evaluate whether variability among ecological sites influenced pasture-scale variability in bare soil, we compared the mean and coefficient of variation in bare soil for all plots within each pasture versus only those plots within the Loamy Plains ecological site. We used this approach because ecological site was a categorical variable assigned to each photograph, and only the Loamy Plains ecological site occurred in all the pasture pairs.

We used a mixed-model analysis of variance (ANOVA) to test for pasture-scale effects of very heavy versus moderate stocking rates and whether this effect interacted with topographic position and distance to water sources. Stocking rate was analyzed within a randomized complete block design applied at the whole-plot level, with TWI and distance to water measured at the subplot level. ANOVAs were implemented with Proc Glimmix (SAS ver. 9.2), using the Laplace approximation for maximum likelihood estimation. We examined different potential distributions and transformations for the response variable and found that using a normal distribution after logarithmic transformation normalized model residuals.

Although data were transformed to meet assumptions for the mixed-model ANOVA, we also present histograms of the frequency distribution of bare soil in each pasture pair to illustrate shifts in the distribution of the amount of bare soil in the $12-\mathrm{m}^{2}$ plots under moderate versus very heavy grazing. For each pair of pastures, we tested for a shift in the bare soil frequency distribution using a Kolmogorov-Smirnov asymptotic two-sample test.

For analyses of spatial autocorrelation in bare soil, we first divided each $12-\mathrm{m}^{2}(3 \times 4 \mathrm{~m})$ photo into two adjacent $6-\mathrm{m}^{2}$ $(3 \times 2 \mathrm{~m})$ plots and calculated bare soil within each $6-\mathrm{m}^{2}$ plot. We then tested for spatial autocorrelation by calculating Moran's I (Sokal and Oden 1978) for each of five distance classes (i.e., distances separating any given pair of plots within a pasture), consisting of $2 \mathrm{~m}$ (each pair of adjacent $6-\mathrm{m}^{2}$ plots), $60-120 \mathrm{~m}, 120-240 \mathrm{~m}, 240-360 \mathrm{~m}$, and $360-480 \mathrm{~m}$, and produced a correlogram by plotting Moran's $I$ versus separation distance (Legendre and Fortin 1989) for each stocking rate. Moran's $I$ provides an index of the strength of autocorrelation in each distance class, where values approaching 1 indicate a complete lack of spatial variation within a distance class (i.e., a homogeneous patch), values approaching -1 indicate maximum dissimilarity among locations within a distance class, and values near zero indicate no departure from random variation (Sokal and Oden 1978). The smallest separation distance class was chosen because autocorrelation at this scale could indicate coalescence of smaller bare patches between plant interspaces. Larger distance classes were chosen because autocorrelation at these scales may be linked to increased bare soil exposure in certain portions of pastures related to distance to water or particular topographic features. We calculated Moran's I and evaluated its statistical significance (i.e., whether Moran's I differs significantly from zero for a given distance class within a given pasture) using the statistical package R. For each separation distance class, we also tested whether mean Moran's I (three replicates per stocking rate) differed between moderate versus very heavy stocking. We used the Moran's I statistic and associated correlogram rather than alternative approaches. such as geostatistics. because we were interested primarily in testing hypotheses about the spatial distribution of bare soil (see Legendre and Fortin 1989; Rossi et al. 1992).

Finally, we examined spatial patterns at scales $<2 \mathrm{~m}$ by quantifying 1) the maximum bare soil intercept length per plot and 2) the number of small $(2-20 \mathrm{~cm})$ bare soil intercepts per plot in each replicate pair of pastures. We used KolmogorovSmirnov tests to assess shifts in the distribution of the maximum bare soil intercept per plot. We used a Poisson log-linear generalized linear model (Agresti 1996), implemented in Proc Genmod (SAS ver. 9.2), to assess differences in counts of the number of small $(2-20 \mathrm{~cm})$ bare soil intercepts per plot in each pair of pastures.

\section{RESULTS}

Bare soil exposure following 3-4 yr of very heavy grazing averaged $22.5 \%$ of a given VLSA image, which was significantly greater than mean bare soil exposure under moderate grazing $(13.5 \% ; P=0.053$; Table 1$)$. When TWI and distance to water were included in the analysis, we found no interaction between the influence of TWI and distance to water on bare soil $(\mathrm{TWI} \times$ distance to water $\times$ stocking rate interaction; $P=0.82$ ), but we did detect significant two-way interactions between TWI and stocking rate $(P=0.014)$ and between distance to water and stocking rate $(P=0.029)$. The model including these two way interactions was

$$
\begin{aligned}
\log (\text { bare soil }+1)= & 1.2354+(0.1834 \times \mathrm{SR}) \\
& +[0.0056-(0.0362 \times \mathrm{SR})] \times \mathrm{TWI} \\
& +[-0.0001-(0.0003 \times \mathrm{SR})] \\
& \times \text { distance to water }
\end{aligned}
$$

where SR = 1 for moderate stocking and 0 for very heavy stocking and distance to water is in meters. These interactions demonstrated that bare soil was negatively correlated with both TWI and distance to water at moderate stocking rates but not at very heavy stocking rates. The relationship with TWI under moderate grazing predicted that bare soil exposure would decline by $13.3 \%$ as TWI increased from a minimum of 1.3 on ridges to a maximum of 28.4 in swales. Similarly, the relationship with distance to water under moderate grazing predicted that mean bare soil would decline by $4.5 \%$ as distance to water increased from 100 to $1000 \mathrm{~m}$.

We examined several metrics of variability in bare soil within pastures. First, for each of the six pastures, the mean and coefficient of variation in bare soil was similar for all plots as compared to only Loamy Plains plots (Table 1), indicating that variation in bare soil was not influenced by ecological site. 
Table 1. Mean percent bare soil in each study pasture (variance, coefficient of variation, and number of very large scale aerial [VLSA] photos per pasture in parentheses) and the mean percent bare soil for areas within each pasture on the Loamy Plains ecological site (variance, coefficient of variation, and number of VLSA photos on the Loamy Plains ecological site per pasture in parentheses) for two stocking rates at the Central Plains Experimental Range in northeastern Colorado.

\begin{tabular}{|c|c|c|c|c|}
\hline & \multicolumn{2}{|c|}{ Whole pasture } & \multicolumn{2}{|c|}{ Loamy Plains ecological site only } \\
\hline & Moderate stocking rate & Very heavy stocking rate & Moderate stocking rate & Very heavy stocking rate \\
\hline Replicate 1 & $17.6(154.5,0.71,87)$ & $22.5(103.5,0.45,49)$ & $15.1(73.9,0.57,55)$ & $22.8(102.4,0.44,46)$ \\
\hline Replicate 2 & $12.3(131.3,0.93,64)$ & $27.6(244.7,0.57,62)$ & $14.3(237.6,1.08,21)$ & $27.8(230.3,0.55,27)$ \\
\hline Replicate 3 & $10.6(42.6,0.62,57)$ & $17.3(53.3,0.42,64)$ & $11.5(46.7,0.59,39)$ & $16.3(45.3,0.41,43)$ \\
\hline Mean & $13.5(109.5,0.75)$ & $22.5(133.8,0.48)$ & $13.6(119.4,0.75)$ & $22.3(126.0,0.47)$ \\
\hline
\end{tabular}

Second, the coefficient of variation in bare soil among plots was significantly lower under very heavy grazing (0.48) compared to moderate grazing (Table $1 ; 0.75$; paired $t=5.47, \mathrm{df}=2$, $P=0.032)$. This is reflected in differences between treatments in the frequency of plots with low $(<10 \%)$ and high $(>30 \%)$ amounts of bare soil (Fig. 1). Under moderate grazing, high coefficients of variation were associated with $44 \%$ of plots having low $(0-10 \%)$ bare soil, while $5 \%$ of plots contained high $(>30 \%)$ bare soil. Under very heavy grazing, only $7 \%$ of plots had low $(0-10 \%)$ bare soil, and $23 \%$ of plots had high $(>30 \%)$ bare soil (Fig. 1). In other words, under very heavy grazing, the frequency of plots with low bare soil declined by $37 \%$, while the frequency of plots with high bare soil increased to a lesser degree (by 18\%) compared to the moderately grazed
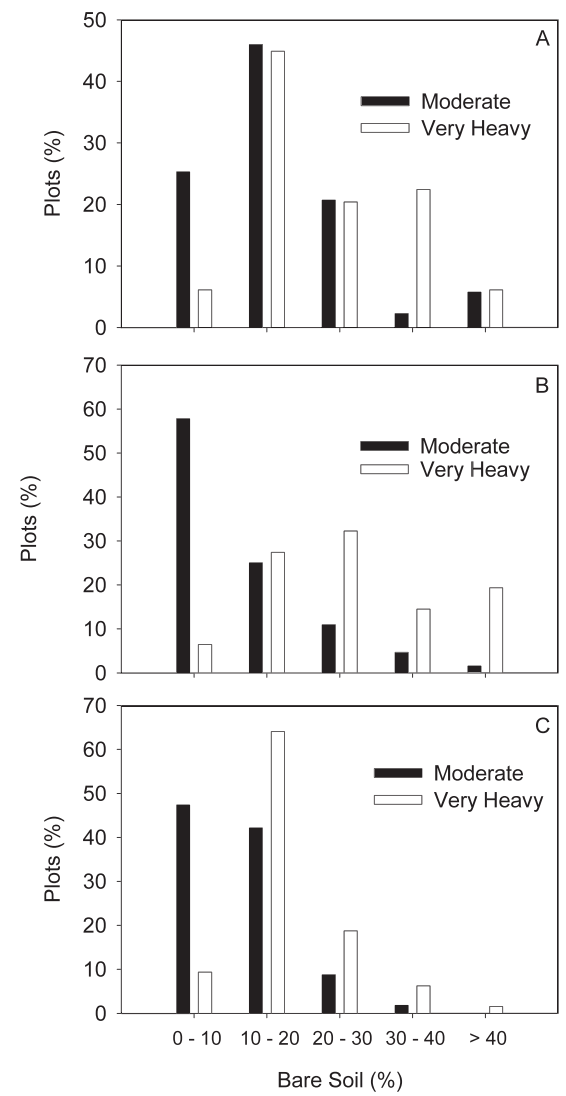

Figure 1. Histograms of the proportion of plots with different levels of bare soil cover for three pairs of pastures at the Central Plains Experimental Range in northeastern Colorado with moderate (0.6 animal unit months $\left.[\mathrm{AUM}] \cdot \mathrm{ha}^{-1}\right)$ versus very heavy $\left(1.2 \mathrm{AUM} \cdot \mathrm{ha}^{-1}\right)$ stocking rate. pastures. Differences in bare soil frequency distribution between moderate versus very heavy grazing were significant based on Kolmogorov-Smirnov tests for each of the 3 blocks (block 1, Fig. 1A: $\mathrm{KSa}=1.512, P=0.021$; block 2, Fig 1B: $\mathrm{KSa}=3.295, P<0.001$; block 3, Fig 1C: KSa $=2.482, P<$ 0.0001). Thus, the shift in the frequency distribution of bare soil within $12-\mathrm{m}^{2}$ plots was consistent across all three replicates.

Bare soil exhibited significant, positive spatial autocorrelation at the $2-\mathrm{m}$ separation distance in all pastures $(P<0.005$ for all six within-pasture autocorrelation tests). Most notably, the magnitude of spatial autocorrection (mean Moran's I) was similar under moderate versus very heavy grazing treatments (Fig. $2 ; 0.58$ vs. 0.48 ; paired $t=0.80, \mathrm{df}=2, P=0.51$ for test of grazing treatment effect on spatial autocorrelation at 2-m separation distance). At larger separation distances, the magnitude of spatial autocorrelation declined, and the rate of decline differed between the grazing treatments. Under moderate grazing at separation distances of 60-120 m, Moran's $I$ indicated significant positive spatial autocorrelation in two of the three pastures $(I>0.15$; test for significance of autocorrelation: $P<0.0001)$ and marginally significant positive autocorrelation $(I=0.07$, test for significance of autocorrelation: $P=0.09$ ) in the third pasture. In contrast, none of the pastures with very heavy grazing exhibited significant spatial

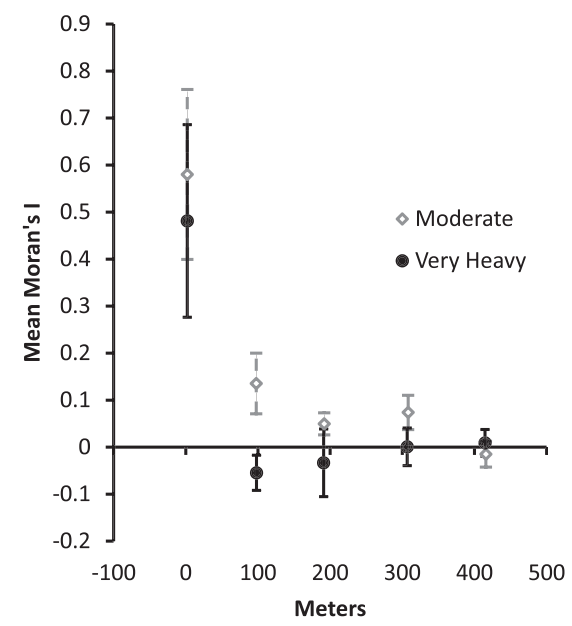

Figure 2. Mean semivariance in bare soil as a function of distance separating the plots based on three pastures with moderate stocking rates and three pastures with very heavy stocking rates at the Central Plains Experimental Range in northeastern Colorado. Error bars show 1 standard error based on variation among the three pastures within each stocking rate treatment. 

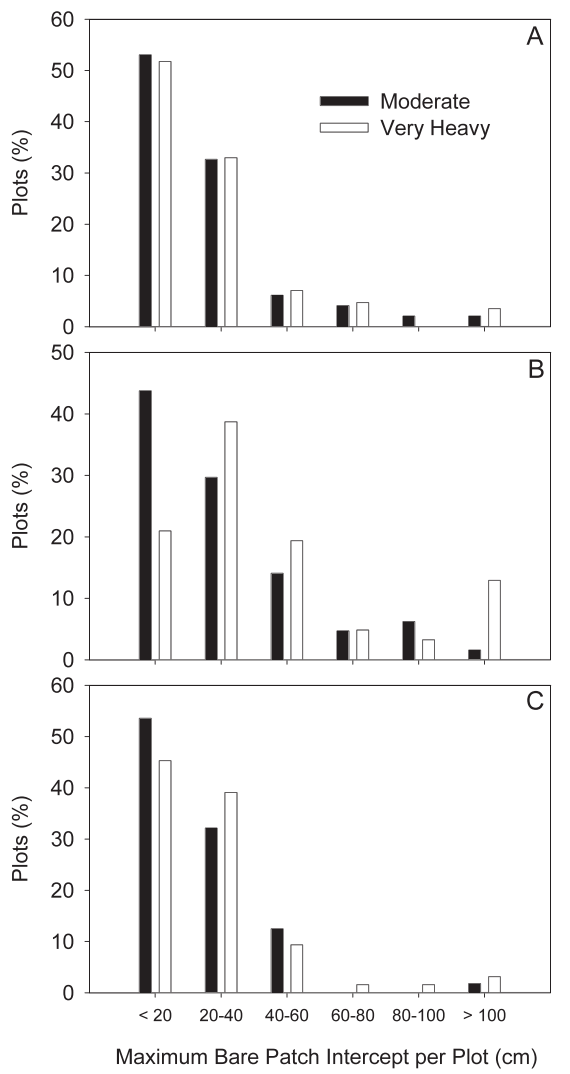

Figure 3 . The relative distribution of very large scale aerial photographs with maximum bare soil intercepts in each of six length classes for three pairs of pastures at the Central Plains Experimental Range in northeastern Colorado. Pastures depicted in panels $\mathbf{A}-\mathbf{C}$ correspond to the grazing replicates 1-3 in Table 1 and Figure 4.

autocorrelation at the 60-120-m separation distance (tests for significance of autocorrelation: $P>0.10)$. Across all three grazing trials, this represents a significant decline in spatial autocorrelation under very heavy stocking compared to moderate grazing at the 60-120-m separation distance (Fig. 2; paired $t=3.74, \mathrm{df}=2, P=0.064)$. At all larger separation distances (120-480 m), we found no significant spatial autocorrelation in bare soil under either stocking rate (Fig. 2). These patterns indicate that most variation in bare soil occurs at small spatial scales $\left(<2 \mathrm{~m}^{2}\right)$ and that patchiness detected at scales of 60 $120 \mathrm{~m}$ in moderately grazed pastures was absent under very heavy grazing.

Because mean bare soil increased under very heavy grazing with no change in the patchiness of bare soil (spatial autocorrelation) at the 2-m separation distance, we further evaluated changes in the distribution of bare soil at scales of 0.02-2 m. Very heavy grazing did not consistently influence the maximum length of bare intercepts measured within plots across the three replicate grazing trials. For the first pasture pair, the distribution of maximum bare intercept lengths was similar for both moderate and very heavy grazing (Fig. 3A, KSa $=0.6318, \mathrm{D}=0.1133, P=0.82$ ), and increased bare soil under very heavy grazing was associated mainly with increased density of small $(2-20 \mathrm{~cm})$ bare intercepts (Fig 4, replicate $1 ; 7.3$ vs. 8.8 intercepts/plot for moderate vs. very heavy grazing; Wald $\left.\chi^{2}=7.94, P=0.0048\right)$. For the second pasture pair, maximum bare intercept length increased in the 40

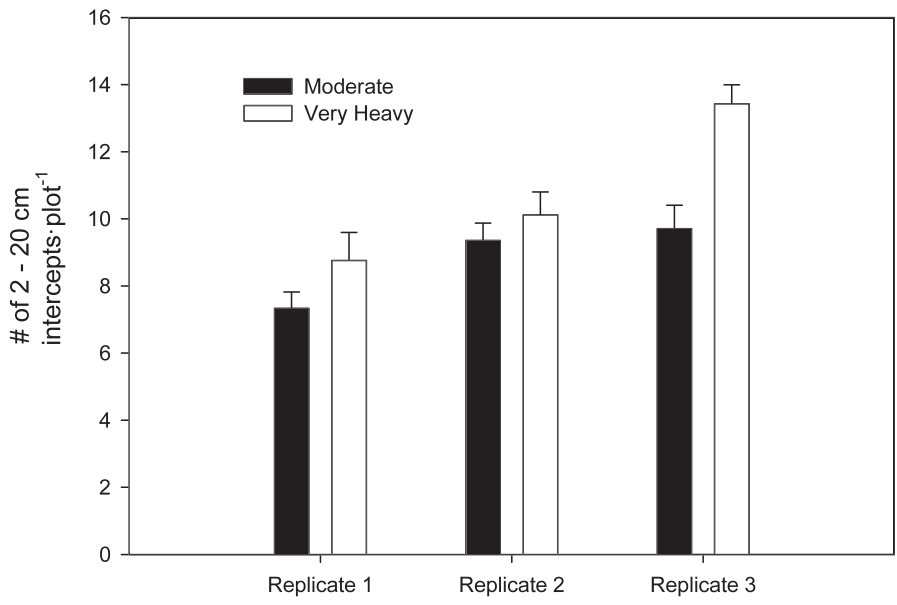

Figure 4. Differences in the density of small $(2-20 \mathrm{~cm})$ bare soil intercepts in $3 \times 4 \mathrm{~m}$ very large scale aerial photographs (mean $\pm 1 \mathrm{SE}$ ) from each of three pairs of pastures at the Central Plains Experimental Range in northeastern Colorado. These three pairs correspond to panels $A-C$ in Figures 1 and 3.

$60-\mathrm{cm}$ and the $>100-\mathrm{cm}$ size classes under very heavy grazing (Fig. 3B, KSa $=1.3831, \mathrm{D}=0.2464, P=0.044$ ), but the density of small $(2-20 \mathrm{~cm})$ bare intercepts did not differ (Fig. 4, replicate 2 ; 9.4 vs. 10.1 intercepts/plot for moderate vs. very heavy grazing; Wald $\left.\chi^{2}=1.83, P=0.18\right)$. For the third pasture pair, we found both increased in frequency of plots with maximum bare intercepts of $20-40 \mathrm{~cm}$ under very heavy grazing (Fig. 3C; $\mathrm{KSa}=1.4028, \mathrm{D}=0.2566, P=0.039)$ and increased density of small $(2-20 \mathrm{~cm})$ bare intercepts for very heavy compared to moderate grazing (Fig. 4, replicate 3; 9.7 vs. 13.4 intercepts/plot; Wald $\left.\chi^{2}=34.53, P<0.0001\right)$. Thus, increased bare soil under very heavy stocking was associated with different fine-scale $(<2 \mathrm{~m})$ spatial patterns in each of the three replicate trials, and we found no consistent stocking rate effect on either the frequency distribution of maximum bare soil intercept lengths or the density of small bare soil intercepts.

\section{DISCUSSION}

Past studies showed that grazing at levels removing $40-60 \%$ of ANPP in shortgrass steppe did not significantly increase bare soil exposure (Milchunas et al. 2008). We found that increasing grazing intensity to stocking rates that remove $70-80 \%$ of annual ANPP over 3-4 consecutive years increased bare soil and altered spatial patterns of vegetation cover. At the same time, the magnitude and direction of these changes still reinforce previous conclusions concerning the high grazing resistance of shortgrass steppe. First, the mean increase in bare soil across all three pasture pairs was $9 \%$ under very heavy versus moderate grazing, with only a $4.9 \%$ increase for the pair receiving $3 \mathrm{yr}$ of treatment and a $6.7-14.3 \%$ increase for the pairs receiving $4 \mathrm{yr}$ of treatment. Second, very heavy stocking did not increase patchiness in bare soil at scales of 2-480 m. Rather, very heavy grazing significantly decreased spatial heterogeneity in bare soil (coefficient of variation; Table 1) by reducing the proportion of the pasture with low (0-10\%) bare soil and removing patchiness at separation distances of 60-120 m (Fig. 3). 
We did find that under very heavy grazing, bare soil increased to a greater degree in swales (i.e., as indexed by plots with high TWI) compared with uplands and increased to a greater degree at locations distant from versus close to water sources. These findings are contrary to our predictions that increased stocking rates would simply increase bare soil in locations where it is greatest under moderate grazing (i.e., near cattle water tanks and in upper topographic positions where plant growth is more water limited) and suggest that cattle may have changed foraging patterns with very heavy stocking. First, the findings suggest that cattle spent more time grazing farther from water under very heavy stocking. However, the pattern with distance to water was weak, which was potentially a result of the small pasture size, where cattle could move from water to the most distant portion of the pasture in any given bout of grazing (Adler and Hall 2005).

Under moderate stocking, our finding that increased TWI was not associated with increased bare soil exposure may be explained by simultaneous increases in plant productivity and grazing intensity with increasing TWI (Milchunas et al. 1989; Varnamkhasti et al. 1995). However, our finding of increased bare soil with greater TWI under the very heavy stocking rate suggests that cattle increased grazing pressure in swales to a greater extent than on uplands with the increased stocking rate. Although this did not lead to the development of large bare soil patches in swales, we note that such a disproportionate increase in lowland grazing intensity can lead to the loss of cool-season perennial grasses often found in swales (Milchunas et al. 2008).

Our findings indicate that although very heavy grazing over 3-4 yr results in a modest increase in the mean amount of bare soil within pastures, this increase was rarely associated with the development of bare soil intercepts larger than $60 \mathrm{~cm}$. Rather, increases in bare soil occurred primarily at the scale of individual plant clusters both through an increase in the density of small bare patches $(2-20-\mathrm{cm}$ intercepts) and through an increase in the frequency of plots with a maximum bare patch intercept of 20-60 cm. In only one of the three grazing trials did the frequency of plots with patches $>1 \mathrm{~m}$ increase notably $(12.9 \%$ of plots under very heavy grazing vs. $1.6 \%$ under moderate grazing). Even here, plots with high bare soil were not aggregated at larger spatial scales (Fig. 2).

We suggest that our approach to quantifying patterns in the distribution of bare soil has significant implications for the hydrology of semiarid rangelands. Where intense grazing increases the size and connectivity of bare patches at scales larger than plant interspaces, we may expect increasing water loss and soil erosion through runoff, with potential feedbacks that accelerate rangeland degradation (e.g., Rietkerk and van de Koppel 1997; Ludwig et al. 2007a). In contrast, where heavy grazing does not increase patchiness at scales of $2-480 \mathrm{~m}$, as we found for the shortgrass steppe, the increase in bare soil at the scale of individual plants and plant clusters may affect primarily evaporative water losses (Lauenroth and Bradford 2006). The magnitude of this effect may depend on soil texture and how plant rooting depth, biomass, and architecture respond to grazing (Reeder et al. 2004; Derner et al. 2006; Lauenroth and Bradford 2006). Future studies are needed to develop quantitative relationships between the size of bare soil patches and soil organic matter storage, root biomass and distribution, and rangeland ecohydrology.

\section{MANAGEMENT IMPLICATIONS}

Bare soil is an important ecological indicator that 1) has a direct relationship to system dynamics and erosion risk (above discussion; Blackburn and Pierson 1994; Ludwig et al. 2007a), 2) has known value for assessing changes in land management and watershed function (Branson et al. 1972; Rostagno 1989), and 3) can be an important measure of habitat suitability for some grassland bird species (Derner et al. 2009). Our novel approach to rangeland monitoring combines 1) measurement of bare soil at spatial scales of individual plants and plant interspaces, 2) rapid collection of such measurements across broad spatial extents (pastures and landscapes), 3) application of spatial statistics to assess patterns in the distribution of bare soil across scales from individual plants to pastures, and 4) integration of these measurements with covariates (topography, water source locations, and ecological sites) that potentially interact with grazing effects on vegetation cover patterns. In the case of the shortgrass steppe, strong spatial autocorrelation in bare soil was detected only at the scale of square meters, and the magnitude of autocorrelation did not increase under very heavy grazing across separation distances of $2-480 \mathrm{~m}$. Our finding of a modest increase in frequency of plots with bare soil intercepts of $0.4-2 \mathrm{~m}$ in only one of three trials indicates a high level of grazing resistance in this rangeland ecosystem. This latter observation of increasing frequency of bare patches on the order of 0.4-2-m diameter may be an important early indicator of pastures and locations that warrant additional management attention.

\section{ACKNOWLEDGMENTS}

We thank Carmen Kennedy and Tyler Odell for analyzing the aerial photographs using SamplePoint, and Carmen Kennedy for analyzing photographs using ImageMeasurement. We thank Crow Valley Livestock Cooperative for providing cattle used in the study and Mary Ashby and Jeff Thomas for animal care and maintaining appropriate stocking rates. We thank Brandon Bestelmeyer, William Lauenroth, Anna Urgeghe, Alexander Smart, and two anonymous reviewers for thoughtful reviews that improved the manuscript.

\section{LITERATURE CITED}

AdleR, P., And S. Hall. 2005. The development of forage production and utilization gradients around livestock watering points. Landscape Ecology 20:319-333.

Adler, P., and W. Lauenroth. 2000. Livestock exclusion increases the spatial heterogeneity of vegetation in Colorado shortgrass steppe. Applied Vegetation Science 3:213-222.

Adler, P., D. Raff, and W. Lauenroth. 2001. The effect of grazing on the spatial heterogeneity of vegetation. Oecologia 128:465-479.

AugustinE, D. J. 2003. Spatial heterogeneity in the herbaceous layer of a semi-arid savanna ecosystem. Plant Ecology 167:319-332.

Augustine, D. J., And D. A. Frank. 2001. Effects of migratory grazers on spatial heterogeneity of soil nitrogen properties in a grassland ecosystem. Ecology 82:3149-3162.

BAKKeR, J. P., J. de LeEuW, ANd S. E. van Wieren. 1983. Micro-patterns in grassland vegetation created and sustained by sheep-grazing. Vegetatio 55:153-161.

Bartley, R., C. H. Roth, J. Ludwig, D. McJannet, A. Liedloff, J. Corfield, A. Hawdon, AND B. ABBotT. 2006. Runoff and erosion from Australia's tropical semi-arid rangelands: influence of ground cover for differing space and time scales. Hydrological Processes 20:3317-3333. 
Bement, R. 1969. A stocking-rate guide for beef production on blue-grama range. Journal of Range Management 22:83-86.

Bestelmeyer, B., J. Ward, and K. Havstad. 2006. Soil-geomorphic heterogeneity governs patch vegetation dynamics at an arid ecotone. Ecology 87:963-973.

BEVEN, K., AND M. KIRKBY. 1979. A physically based, variable contributing area model of basin hydrology. Hydrological Sciences Bulletin 24:43-68.

BlackBuRn, W. H., And F. B. Pierson, Jr. 1994. Sources of variation in interrill erosion on rangelands. In: Variability of rangeland water erosion processes, Special Publication 38. Madison, WI, USA: Soil Science Society of America. p. 1-9.

Booth, D. T., AND S. E. Cox. 2008. Image-based monitoring to measure ecological change. Frontiers in Ecology and the Environment 6:185-190.

Booth, D. T., S. E. Cox, and R. D. Berryman. 2006a. Point sampling digital imagery with "SamplePoint." Environmental Monitoring and Assessment 123:97-108.

Booth, D. T., S. E. Cox, and R. D. Berryman. 2006b. Precision measurements from very-large scale aerial digital imagery. Environmental Monitoring and Assessment 112:293-307.

Branson, F. A., G. F. Gifford, and J. R. Owen. 1972. Rangeland hydrology. Denver, CO, USA: Society for Range Management. Range Science Series No. 1. 84 p.

Coffin, D. P., W. K. Lauenroth, and I. C. Burke. 1996. Recovery of vegetation in a semiarid grassland 53 years after disturbance. Ecological Applications 6:538-555.

Derner, J. D., T. W. Boutton, and D. D. Briske. 2006. Grazing and ecosystem carbon storage in the North American Great Plains. Plant and Soil 28:77-90.

Derner, J. D., W. K. Lauenroth, P. Stapp, and D. J. Augustine. 2009. Livestock as ecosystem engineers for grassland bird habitat in the western Great Plains of North America. Rangeland Ecology \& Management 62:111-118.

Funlendorf, S., and F. Smeins. 1999. Scaling effects of grazing in a semi-arid grassland. Journal of Vegetation Science 10:731-738.

Hart, R. H., And M. A. Ashby. 1998. Grazing intensities, vegetation, and heifer gains: 55 years on shortgrass. Journal of Range Management 51:392-398.

Herrick, J., J. Van Zee, K. Havstad, L. Burkett, and W. Whitford. 2005. Monitoring manual for grassland, shrubland and savanna ecosystems. Volume 2. Las Cruces, NM, USA: USDA-ARS Jornada Experimental Range. 200 p.

Interagency TeChNical Team. 1996. Sampling vegetation attributes. Denver, CO, USA: US Department of the Interior, Bureau of Land Management-National Applied Resources Science Center, Interagency Technical Reference Report BLM/RS/ ST-96/002. $164 \mathrm{p}$.

Kefi, S., M. Rietkerk, C. Alados, Y. Pueyo, V. Papanastasis, A. El Aich, and P. De Ruiter. 2007. Spatial vegetation patterns and imminent desertification in Mediterranean arid ecosystems. Nature 449:213-218.

Klausmeier, C. A. 1999. Regular and irregular patterns in semiarid vegetation. Science 284:1826-1828.

LaUenRoth, W. K., and J. B. BradFord. 2006. Ecohydrology and the partitioning of AET between transpiration and evaporation in semiarid steppe. Ecosystems 9:756-767.

Lauenroth, W. K., and I. C. Burke. 2008. Ecology of the shortgrass steppe. New York, NY, USA: Oxford University Press. $522 \mathrm{p}$.

Lauenroth, W. K., I. C. Burke, and M. P. Gutmann. 1999. The structure and function of ecosystems in the central North American grassland region. Great Plains Research 9:223-260.

Legendre, P., And M. Fortin. 1989. Spatial pattern and ecological analysis. Vegetatio 80:107-138.

Ludwig, J. A., R. Bartley, A. A. Hawdon, B. N. Abbott, and D. McJannet. 2007a. Patch configuration non-linearly affects sediment loss across scales in a grazed catchment in north-east Australia. Ecosystems 10:839-845.

Ludwig, J. A., G. N. Bastin, J. F. Wallace, and T. R. McVicar. 2007b. Assessing landscape health by scaling with remote sensing: when is it not enough? Landscape Ecology 22:163-169.

Ludwig, J. A., B. P. Wilcox, D. D. Breshears, D. J. Tongway, and A. C. Imeson. 2005. Vegetation patches and runoff-erosion as interacting ecohydrological processes in semiarid landscapes. Ecology 86:288-297.
Mllchunas, D. G., J. Forwood, and W. K. Lauenroth. 1994. Productivity of long-term grazing treatments in response to seasonal precipitation. Journal of Range Management 47:133-139.

Milchunas, D. G., and W. K. Lauenroth. 1989. Three-dimensional distribution of plant biomass in relation to grazing and topography in the shortgrass steppe. Oikos 55:82-86.

Milchunas, D. G., and W. K. Lauenroth. 1993. Quantitative effects of grazing on vegetation and soils over a global range of environments. Ecological Monographs 63:327-366.

Milchunas, D. G., W. K. Lauenroth, I. Burke, and J. K. Detling. 2008. Effects of grazing on vegetation. In: W. Lauenroth and I. C. Burke [EDS.]. Ecology of the shortgrass steppe: a long-term perspective. New York, NY, USA: Oxford University Press. p. 389-446.

Milchunas, D. G., W. K. Lauenroth, P. L. Chapman, and M. K. Kazempour. 1989. Effects of grazing, topography and precipitation on the structure of a semiarid grassland. Vegetatio 80:11-23.

Pringle, H. J. R., and J. Landsberg. 2004. Predicting the distribution of livestock grazing pressure in rangelands. Austral Ecology 29:31-39.

Reeder, J. D., G. E. Schuman, J. A. Morgan, and D. R. Lecain. 2004. Response of organic and inorganic carbon and nitrogen to long-term grazing of the shortgrass steppe. Environmental Management 33:485-495.

Rietkerk, M., P. Ketner, J. Burger, B. Hoorens, and H. Olff. 2000. Multiscale soil and vegetation patchiness along a gradient of herbivore impact in a semi-arid grazing system in West Africa. Plant Ecology 148:207-224.

RietKerk, M., and J. van de Koppel. 1997. Alternate stable states and threshold effects in semi-arid grazing systems. Oikos 79:69-76.

Rossi, R. E., D. J. Mulla, A. G. Journel, and E. H. Franz. 1992. Geostatistical tools for modeling and interpreting ecological spatial dependence. Ecological Monographs 62:277-314.

Rostagno, C. 1989. Infiltration and sediment production as affected by soil surface conditions in a shrubland of Patagonia, Argentina. Journal of Range Management 42:382-385.

Sasaki, T., T. Okayasu, U. Jamsran, and K. Takeuchi. 2008. Threshold changes in vegetation along a grazing gradient in Mongolian rangelands. Journal of Ecology 96:145-154.

Seefeldt, S. S., AND D. T. Booth. 2006. Measuring plant cover in sagebrush steppe rangelands: a comparison of methods. Environmental Management 37:703-711.

SokAL, R., And N. Oden. 1978. Spatial autocorrelation in biology 2. Some biological implications and four applications of evolutionary and ecological interest. Biological Journal of the Linnean Society 10:229-249.

Stokes, C. J., R. I. Yeaton, M. B. Bayer, and B. T. Bestelmeyer. 2009. Indicator patches: exploiting spatial heterogeneity to improve monitoring systems. The Rangeland Journal 31:385-394.

Theobald, D. M. 2007. LCaP v1.0: Landscape connectivity and pattern tools for ArcGIS. Fort Collins, CO, USA: Colorado State University. Available at: http:// warnercnr.colostate.edu/ davet/LCaP.html. Accessed 19 December 2011.

Urgeghe, A., D. Breshears, S. Martens, and P. Beeson. 2010. Redistribution of runoff among vegetation patch types: on ecohydrological optimality of herbaceous capture of run-on. Rangeland Ecology \& Management 63:497-504.

[USDA, nRCS] US Department of Agriculture, Natural Resources Conservation Service. 2007. Ecological site description for: Loamy Plains, MLRA 067BCentral High Plains, Southern Part. Available at: http://esis.sc.egov.usda.gov/ ESDReport/fsReport.aspx?id=R067BY002C0. Accessed 13 September 2010.

Varnamkhasti, A., D. Milchunas, W. Lauenroth, and H. Goetz. 1995. Production and rain use efficiency in short-grass steppe: grazing history, defoliation and water resource. Journal of Vegetation Science 6:787-796.

Watson, I., P. Novelly, and P. Thomas. 2007. Monitoring changes in pastoral rangelands with the Western Australian Rangeland Monitoring System (WARMS). The Rangeland Journal 29:191-205.

Weber, G., F. Jeltsch, N. van Rooyen, and S. Milton. 1998. Simulated long-term vegetation response to grazing heterogeneity in semi-arid rangelands. Journal of Applied Ecology 35:687-699. 